\title{
Investigation on Surface Roughness of Inconel 718 in Photochemical Machining
}

\author{
Nitin D. Misal ${ }^{1}$ and Mudigonda Sadaiah ${ }^{2}$ \\ ${ }^{1}$ Department of Mechanical Engineering, SVERI's College of Engineering Pandharpur, Maharashtra 413304, India \\ ${ }^{2}$ Department of Mechanical Engineering, Dr. Babasaheb Ambedkar Technological University, Lonere, Raigad, \\ Maharashtra 402103, India
}

Correspondence should be addressed to Nitin D. Misal; nitin.misal72@gmail.com

Received 26 August 2016; Accepted 27 December 2016; Published 29 January 2017

Academic Editor: Patrice Berthod

Copyright (c) 2017 Nitin D. Misal and Mudigonda Sadaiah. This is an open access article distributed under the Creative Commons Attribution License, which permits unrestricted use, distribution, and reproduction in any medium, provided the original work is properly cited.

\begin{abstract}
The present work is focused on estimating the optimal machining parameters required for photochemical machining (PCM) of an Inconel 718 and effects of these parameters on surface topology. An experimental analysis was carried out to identify optimal values of parameters using ferric chloride $\left(\mathrm{FeCl}_{3}\right)$ as an etchant. The parameters considered in this analysis are concentration of etchant, etching time, and etchant temperature. The experimental analysis shows that etching performance as well as surface topology improved by appropriate selection of etching process parameters. Temperature of the etchant found to be dominant parameter in the PCM of Inconel 718 for surface roughness. At optimal etching conditions, surface roughness was found to be $0.201 \mu \mathrm{m}$.
\end{abstract}

\section{Introduction}

The Inconel 718 superalloy has a variety of industrial applications like aircraft engines, submarines, space vehicles, and so forth due to its distinctive properties. However, machining of this material becomes one of the key issues due to its hard nature. Photochemical machining is nontraditional micromachining processes. It produces flat metallic components which are free from burr and stress. In PCM, metal removal takes place through dissolution of metal atoms in chemical solution. It involves etching of metal from the restricted area using photo tool assisted photoresist. In present days, the PCM is acting a vital role in the precision parts manufacturing in industries like aerospace, automobile, electronics, ornament, medical, and so forth. The products made by using PCM are useful in the microelectromechanical system (MEMS) and nanoelectromechanical system (NEMS) [1,2].

Inconel 718 is an important nickel based super alloy and it is used for various engineering applications. It especially is used in aerospace, marine, nuclear, and food processing applications [3]. This nickel alloy resists spalling during temperature fluctuations by developing a tightly sticking oxide scale. Inconel 718 has applications in high temperature and high pressure condition [4].

Saraf and Sadaiah studied effect of magnetic field on the etch rate of SS316L [5]. Patil and Mudigonda conducted experiments on Inconel 718 for understanding the effects of control variables such as speed of cutting, rate of feed, and depth of cut on surface finish and residual stresses at different level of parameters [6]. Qu et al. carried out the study on Monel 400 using PCM. Study shows that rolling direction affects etch rate [7]. For the first time Bruzzone and Reverberi introduced simulation in PCM. For this, a 2D Monte Carlo simulation model was used and experimental value was performed [8]. Çakir studied the effect of ferric chloride etchant on Aluminum as $\mathrm{Al}$ etching is the critical issue in the PCM industry [9]. Ho et al. performed the chemical machining, analysis of nanocrystalline nickel and predicted the effect of etchant concentration on etching quality [10]. Çakir et al. carried out comparative analysis of the copper etching process with ferric chloride and cupric chloride etchant. Etching rate was observed more with ferric chloride etchant while smooth surface quality was produced with cupric chloride etchant [11]. Allen and Almond discussed 


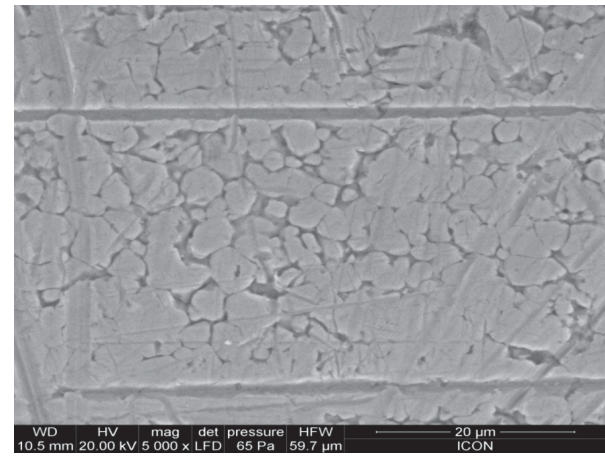

FIGURE 1: SEM image of Inconel 718 before machining.

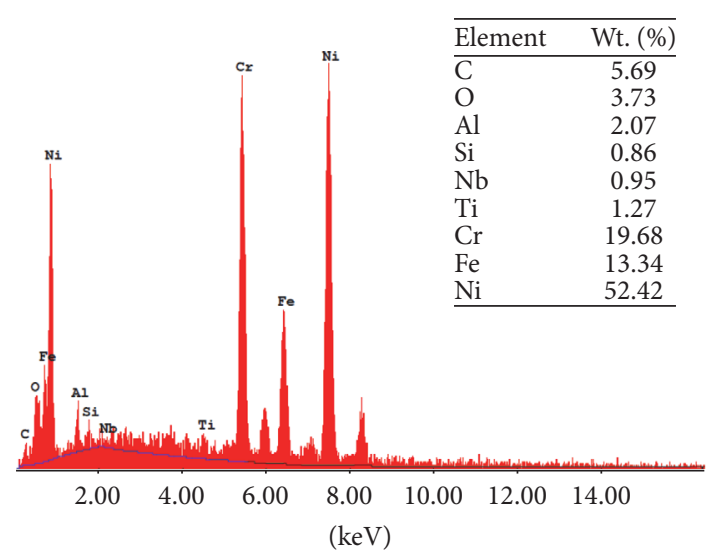

Figure 2: EDAX profile of Inconel 718.

issues in Quality Control (QC) for ferric chloride etchant in PCM Industries [12].

Literature shows that no investigation has been reported on surface topology in PCM. Inconel 718 is a difficult to cut alloy and it is having wide range of applications. It can be machined using Electro Discharge Machining, laser beam machining, and so forth where stresses are induced during machining. The PCM is stress and burr free process in which no significant study has been observed on Inconel alloys. The effect of process parameter on surface topology is a critical issue in PCM. This study investigates the photochemical machining of Inconel 718 for the first time.

\section{Materials and Methods}

2.1. Material. The material selected for experimentation was Inconel 718 . The plate of $250 \times 250 \times 1 \mathrm{~mm}$ was taken initially for measurement of surface roughness value. The initial values of surface roughness were taken at different places on the workpiece and the average value was observed as $1.98 \mu \mathrm{m}$. The specimens were prepared in size of $20 \times 20 \mathrm{~mm}$. The scanning electron microscopy (SEM) image of unmachined Inconel 718 is as shown in Figure 1. Energy Dispersive X-Ray Analysis (EDAX) profile as presented in Figure 2 provides the chemical composition of Inconel 718.

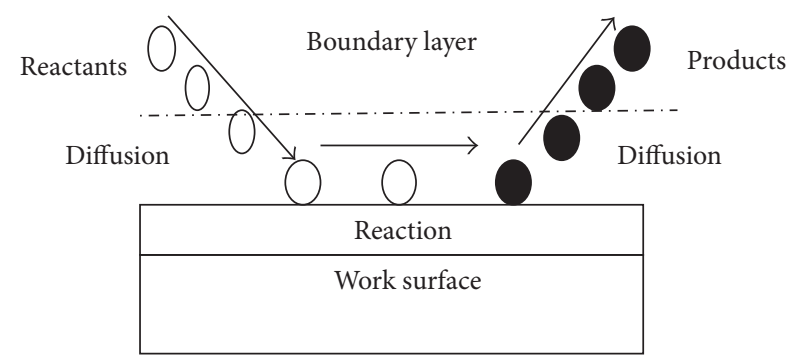

FIgURE 3: Photochemical machining mechanism.

TABLE 1: Input parameters.

\begin{tabular}{lccc}
\hline \multirow{2}{*}{ Parameter } & \multicolumn{3}{c}{ Levels for experimentation } \\
& Level 1 & Level 2 & Level 3 \\
\hline Temperature $\left({ }^{\circ} \mathrm{C}\right)$ & 45 & 50 & 55 \\
Etchant conc. $(\mathrm{g} / \mathrm{L})$ & 500 & 550 & 600 \\
Time $(\mathrm{min})$ & 20 & 30 & 40 \\
\hline
\end{tabular}

2.2. Machining Mechanism. In photochemical machining, metal removal takes place by etching. There are three major stages observed (Figure 3).

(a) Ions or molecules from etchant solution diffused towards the exposed film on the work surface through the boundary layer.

(b) Due to chemical reaction between etchant exposed film soluble and gaseous byproducts formation takes place.

(c) A byproduct from the surface of work piece gets diffused through the boundary layer into the etchant solution.

2.3. Experimental Procedure. The different steps followed in PCM experimentation are given in Figure 4.

The specimens were cleaned by using ultrasonic cleaner. Solution used for cleaning contains deionizer water with the $1 \%$ of hydrochloric acid. The cleaned surface was observed under SEM for surface alterations and EDAX for the chemical composition. The specimens were machined by using $\mathrm{FeCl}_{3}$ (ferric chloride) as etchant. The design of experiments is based on full factorial (3k) methodology. From past literature, it has been observed that the parameters which have significant effect on the response parameter of PCM [1318] are concentration of etchant, etching temperature, and etching time. The preliminary experimentation has been carried out by using one factor at a time method for deciding the ranges of process parameters. The process parameters selected are etchant concentration, etchant temperature, and etching time with three levels each as shown in Table 1. For this combination of process parameters, 27 experiments are required to be carried out using a full factorial method. Also, response parameter as surface roughness $\left(R_{a}\right)$ values is included in Table 2. 
TABLE 2: Experimental layout with coded and actual values.

\begin{tabular}{|c|c|c|c|c|c|c|c|}
\hline \multirow[b]{2}{*}{ Run } & \multicolumn{3}{|c|}{ Coded values } & \multicolumn{3}{|c|}{ Actual values } & \multirow[b]{2}{*}{$\begin{array}{l}\text { Surface finish } \\
\qquad R_{a}(\mu \mathrm{m})\end{array}$} \\
\hline & Temperature $\left({ }^{\circ} \mathrm{C}\right)$ & Concentration $(\mathrm{g} / \mathrm{L})$ & $\begin{array}{l}\text { Time } \\
(\mathrm{min}) \\
\end{array}$ & Temperature $\left({ }^{\circ} \mathrm{C}\right)$ & $\begin{array}{c}\text { Concentration } \\
(\mathrm{g} / \mathrm{L})\end{array}$ & $\begin{array}{l}\text { Time } \\
(\mathrm{min})\end{array}$ & \\
\hline 01 & 1 & 1 & 1 & 45 & 500 & 20 & 0.660 \\
\hline 02 & 1 & 1 & 2 & 45 & 500 & 30 & 0.535 \\
\hline 03 & 1 & 1 & 3 & 45 & 500 & 40 & 0.480 \\
\hline 04 & 1 & 2 & 1 & 45 & 550 & 20 & 0.479 \\
\hline 05 & 1 & 2 & 2 & 45 & 550 & 30 & 0.462 \\
\hline 06 & 1 & 2 & 3 & 45 & 550 & 40 & 0.457 \\
\hline 07 & 1 & 3 & 1 & 45 & 600 & 20 & 0.450 \\
\hline 08 & 1 & 3 & 2 & 45 & 600 & 30 & 0.418 \\
\hline 09 & 1 & 3 & 3 & 45 & 600 & 40 & 0.399 \\
\hline 10 & 2 & 1 & 1 & 50 & 500 & 20 & 0.390 \\
\hline 11 & 2 & 1 & 2 & 50 & 500 & 30 & 0.375 \\
\hline 12 & 2 & 1 & 3 & 50 & 500 & 40 & 0.339 \\
\hline 13 & 2 & 2 & 1 & 50 & 550 & 20 & 0.298 \\
\hline 14 & 2 & 2 & 2 & 50 & 550 & 30 & 0.297 \\
\hline 15 & 2 & 2 & 3 & 50 & 550 & 40 & 0.296 \\
\hline 16 & 2 & 3 & 1 & 50 & 600 & 20 & 0.281 \\
\hline 17 & 2 & 3 & 2 & 50 & 600 & 30 & 0.278 \\
\hline 18 & 2 & 3 & 3 & 50 & 600 & 40 & 0.271 \\
\hline 19 & 3 & 1 & 1 & 55 & 500 & 20 & 0.268 \\
\hline 20 & 3 & 1 & 2 & 55 & 500 & 30 & 0.257 \\
\hline 21 & 3 & 1 & 3 & 55 & 500 & 40 & 0.252 \\
\hline 22 & 3 & 2 & 1 & 55 & 550 & 20 & 0.210 \\
\hline 23 & 3 & 2 & 2 & 55 & 550 & 30 & 0.207 \\
\hline 24 & 3 & 2 & 3 & 55 & 550 & 40 & 0.207 \\
\hline 25 & 3 & 3 & 1 & 55 & 600 & 20 & 0.205 \\
\hline 26 & 3 & 3 & 2 & 55 & 600 & 30 & 0.203 \\
\hline 27 & 3 & 3 & 3 & 55 & 600 & 40 & 0.201 \\
\hline
\end{tabular}

2.4. Experimental Setup. Experimental set-up for PCM of Inconel 718 is shown in Figure 5. Etching bath is used for carrying out experiments. It consists of an insulated cover which maintains the temperature inside the bath. The temperature controller is used to control the temperature of the bath with accuracy of $\pm 1^{\circ} \mathrm{C}$. The measurement of surface finish $\left(R_{a}\right)$ was carried out by using Taylor Hobson talysurf profilometer.

\section{Results and Discussion}

The statistical analysis for the influence of process variables on surface roughness was made with the help of Mean Effective Plots and Analysis of Variance (ANOVA). Thus, the effect of process variables on response parameters was analyzed to obtain optimized condition for low surface roughness and a high material removal rate.

3.1. Analysis of Surface Roughness $\left(R_{a}\right)$. Table 3 shows the analysis of variance (ANOVA) for surface roughness. From
ANOVA results, it was observed that the effects of process parameters are significant on surface finish values. For temperature and concentration it shows selected range is nearly $100 \%$ significant and for the time it is about 95.1\% significant. The most statistically significant factor was temperature.

Figure 6 indicates the main effect plot for the surface roughness of the photochemically machined Inconel 718 . The main effect plots showed that the surface roughness was decreased with an increase in levels of input parameters. The etching temperature, concentration, and time in decreasing order of importance are control variables having an effect on $R_{a}$.

At $45^{\circ} \mathrm{C}$ temperature, the reaction of ferric chloride with Inconel 718 was just initiated, so initially the surface roughness was observed more. As the temperature increases, the viscosity of etchant reduces. Therefore, it results in improved penetration of cation across the diffusion layer. At high temperature, etchant attack is not along the grain boundaries but rather distributed over grain areas, leading to 
TABLE 3: Summary of ANOVA for surface roughness.

\begin{tabular}{|c|c|c|c|c|c|}
\hline Source & Degree of freedom & Adj. sum of square & Adj. mean of square & $F$-value & $P$ value \\
\hline Temperature & 2 & 0.310680 & 0.155340 & 167.80 & 0.000 \\
\hline Concentration & 2 & 0.043659 & 0.021830 & 23.58 & 0.000 \\
\hline Time & 2 & 0.006500 & 0.003250 & 3.51 & 0.049 \\
\hline Error & 20 & 0.018515 & 0.000926 & & \\
\hline Total & 26 & 0.379354 & & & \\
\hline
\end{tabular}

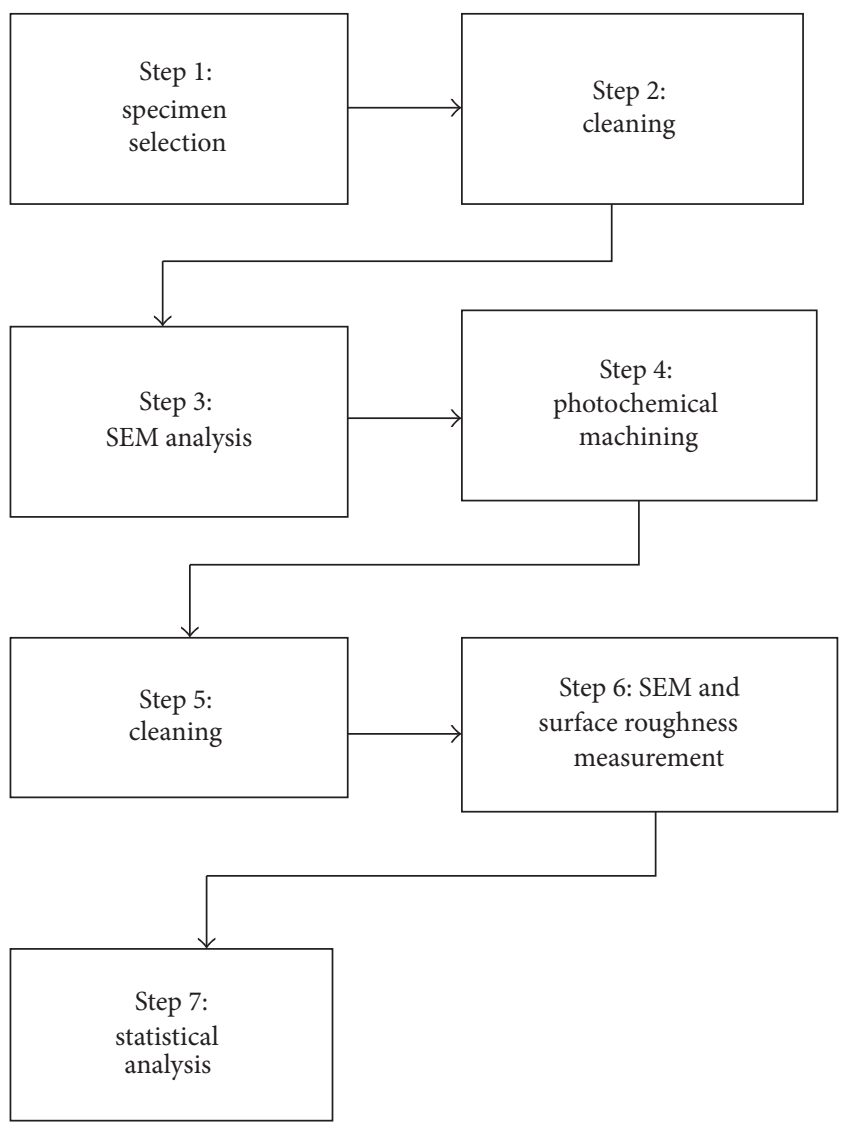

FIgURE 4: Flow chart of PCM experimentation.

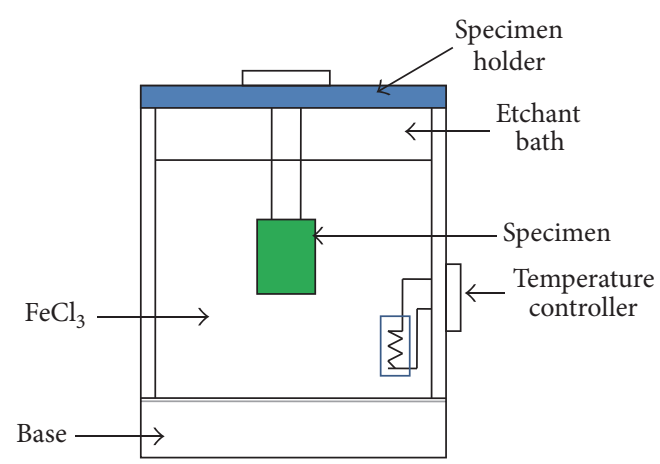

FIgURE 5: Experimental set-up.
TABLE 4: Summary of ANOVA for surface roughness.

\begin{tabular}{lccc}
\hline $\begin{array}{l}\text { Concentration } \\
\text { in grams/liters }\end{array}$ & $\begin{array}{c}\text { Sample weight } \\
\text { before etching } \\
\text { in grams }\end{array}$ & $\begin{array}{c}\text { Sample weight } \\
\text { after etching in } \\
\text { grams }\end{array}$ & $\begin{array}{c}\text { Weight loss } \\
\text { in grams }\end{array}$ \\
\hline (A) 500 & 0.977 & 0.958 & 0.019 \\
(B) 550 & 0.971 & 0.956 & 0.015 \\
(C) 600 & 0.982 & 0.970 & 0.012 \\
\hline
\end{tabular}

a smoother surface. Hence it was seen from main effect plots as the temperature increases, the surface roughness decreases.

It was seen that as the concentration of etchant increases, etching rate decreases (as shown in Table 4 and Figure 7).

When etchant concentration is high, movement of cation across the diffusion layer becomes difficult as ferric chloride becomes more viscous. Thus, the reduced rate of diffusion leads to better surface finish. The time of reaction has a very less effect on surface roughness as temperature and concentration play a vital role for machining purposes.

Figure 8 shows the interaction plots between control parameter and the response variable. It can be seen that there is a significant decrease in the surface roughness value with increase in temperature, concentration, and time. As temperature increases the surface roughness value decreases; for $500 \mathrm{~g} / \mathrm{L}$ concentration at temperature $45^{\circ} \mathrm{C}$ the average surface roughness value recorded was $0.56 \mu \mathrm{m}$ and at $55^{\circ} \mathrm{C}$ it was $0.259 \mu \mathrm{m}$ (refer Figure 8(a)). The time is less significant parameter for surface roughness as there is very less change in surface roughness values with increase in time for the constant temperature as shown in Figure 8(b). For 20minute etching time, average $0.44 \mu \mathrm{m}$ surface roughness was recorded for $500 \mathrm{~g} / \mathrm{L}$ concentration and $0.31 \mu \mathrm{m}$ for $600 \mathrm{~g} / \mathrm{L}$ concentration (refer to Figure 8(c)).

\subsection{Surface Morphology}

3.2.1. SEM Analysis. Figure 9(a) shows the microstructure of unmachined Inconel 718 and Figure 9(b) shows the microstructure of Inconel 718 after machining. Using optimum etching parameter of $55^{\circ} \mathrm{C}$ temperature, $600 \mathrm{~g} / \mathrm{L}$, and 40 minutes time of etching the machining of Inconel 718 was carried out. The machined surface gives smaller grain size as compared to the unmachined surface. The machined surface also shows small clusters of alloying element chlorides which may adhere to the machined surface due to fusion. 


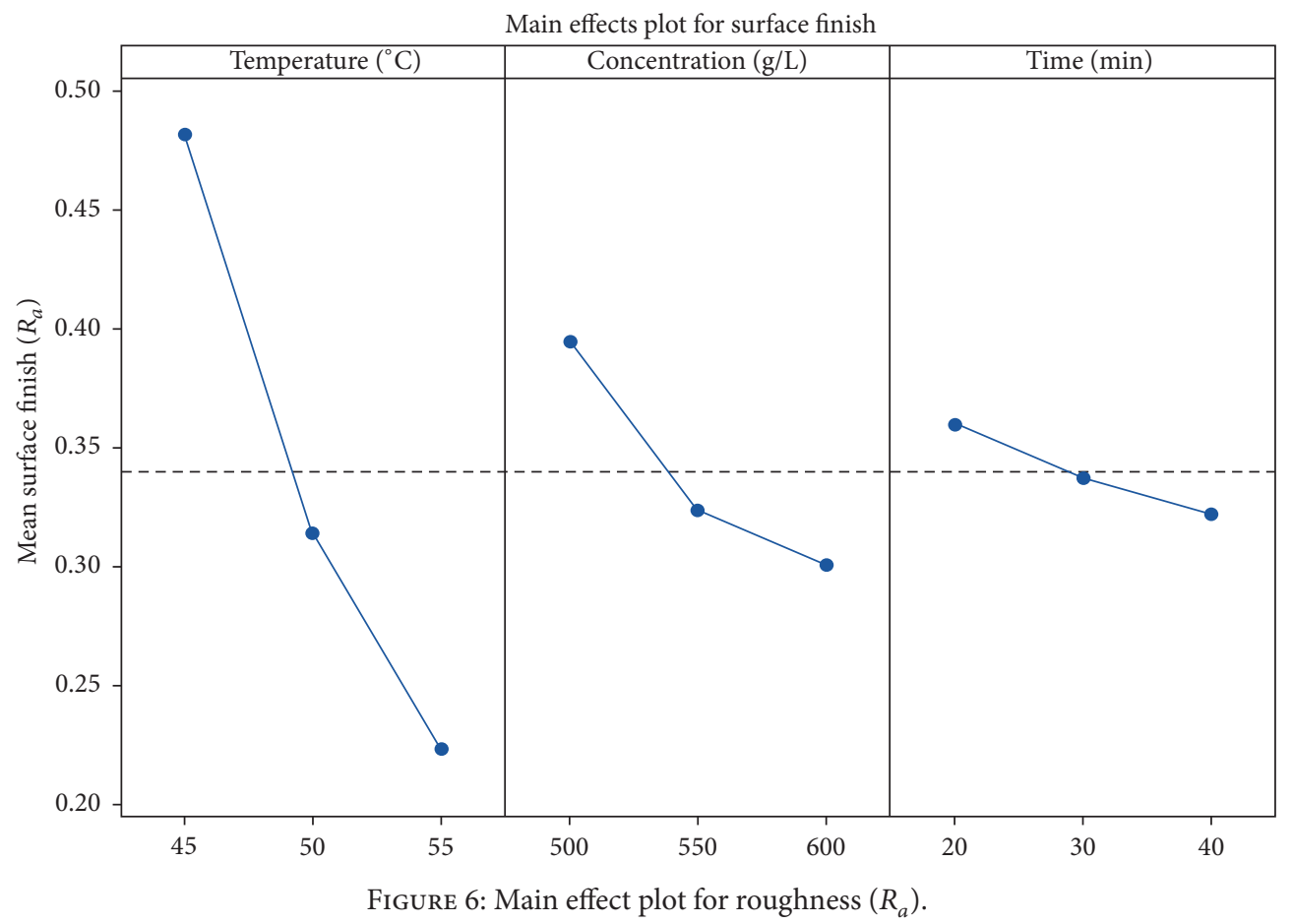

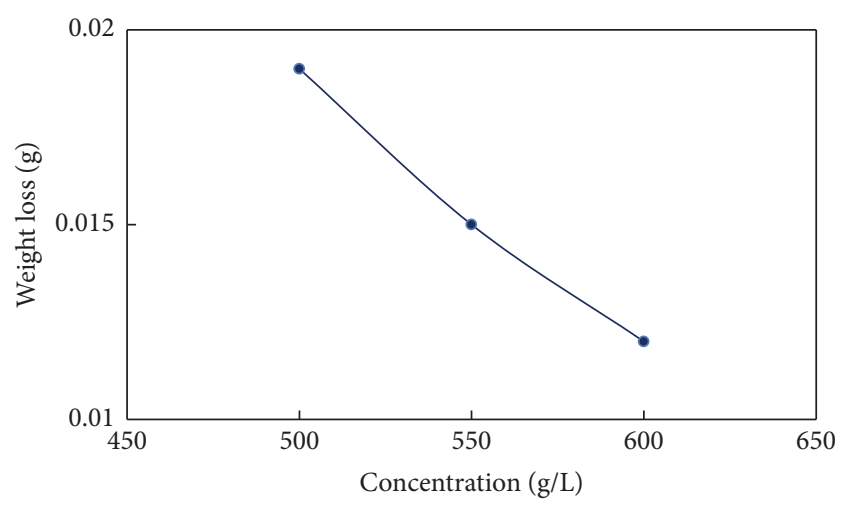

FIGURE 7: Graph of sample weight loss against concentration at $50^{\circ} \mathrm{C}$ and 20 Minutes of etching.

3.2.2. Sample Microstructure of Inconel 718. The microstructure of the Inconel 718 samples after machining was examined with Nikon microscope. The microstructure of specimens before machining is shown in Figure 10(a) and after machining is shown in Figures 10(b), 10(c), and 10(d) for constant concentration of etching solution at $600 \mathrm{~g} / \mathrm{L}$ and time of etching at $40 \mathrm{~min}$. with change in temperature as $45^{\circ} \mathrm{C}$, $50^{\circ} \mathrm{C}$, and $55^{\circ} \mathrm{C}$, respectively. There is a significant effect of etchant temperature observed on the microstructure and the machining marks become smoother with an increase in the temperature.

As the temperature is increased from $45^{\circ} \mathrm{C}$ to $55^{\circ} \mathrm{C}$ the surface roughness decreases. At temperatures $45^{\circ} \mathrm{C}, 50^{\circ} \mathrm{C}$, and $55^{\circ} \mathrm{C}$, the roughness value $R_{a}$ is found to be $0.399 \mu \mathrm{m}$, $0.271 \mu \mathrm{m}$, and $0.210 \mu \mathrm{m}$, respectively, and the roughness profile for the same is shown in Figures 11, 12, and 13.
The material removal initiated by the corrosion phenomenon in photochemical machining. The formation of passive layers is generally affected by chloride ions which eventually lead to corrosion. Very less corrosion sites are nucleated at low temperature and thus a rough and undesirable surface is produced. At higher etchant temperatures, corrosion sites nucleated are more which gives uniform corrosion and leave a better surface finish. This can be seen from Figure 14 . At lower temperature $\left(45^{\circ} \mathrm{C}\right)$ void formation is observed (Figure 14(a)) resulting in higher surface roughness. The good intergranular and intragranular corrosion during etching (Figure 14(b)) is observed which leads to a better surface roughness at higher temperature $\left(55^{\circ} \mathrm{C}\right)$.

\section{Conclusions}

For machining of Inconel 718, photochemical machining is found to be a suitable machining process. The experimental investigation was carried out to analyze the influence of control variables on surface roughness in PCM. Findings of the above study are as follows:

(i) Higher temperature resulted in better surface finish as the etchant reacts with more grain area for uniform surface alterations.

(ii) As the etchant concentration increases, the surface roughness decreases.

(iii) The optimum surface finish, $R_{a}$ as $0.201 \mu \mathrm{m}$ was observed at temperature $55^{\circ} \mathrm{C}$, etchant concentration $600 \mathrm{~g} / \mathrm{L}$, and time $40 \mathrm{~min}$.

(iv) Time shows less effect on surface roughness as compared to temperature and concentration. 

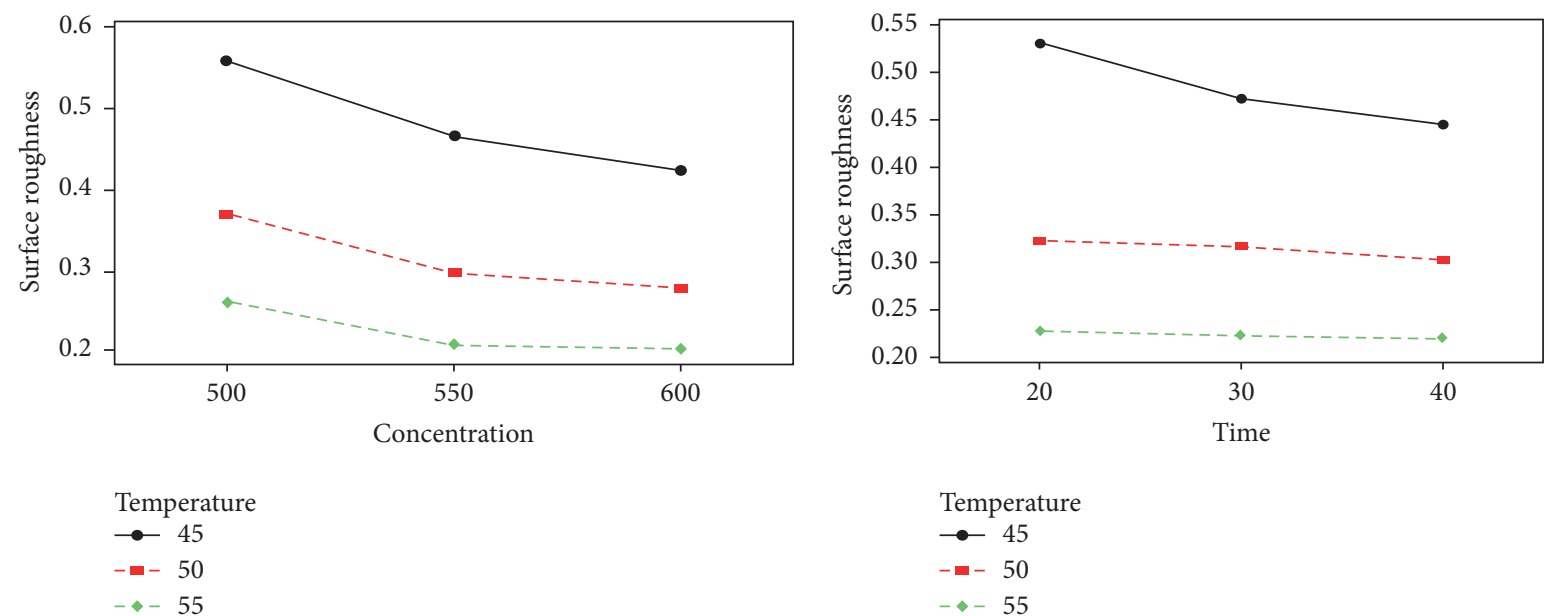

Temperature

$\rightarrow 45$

$-50$

$--55$

(a)

(b)

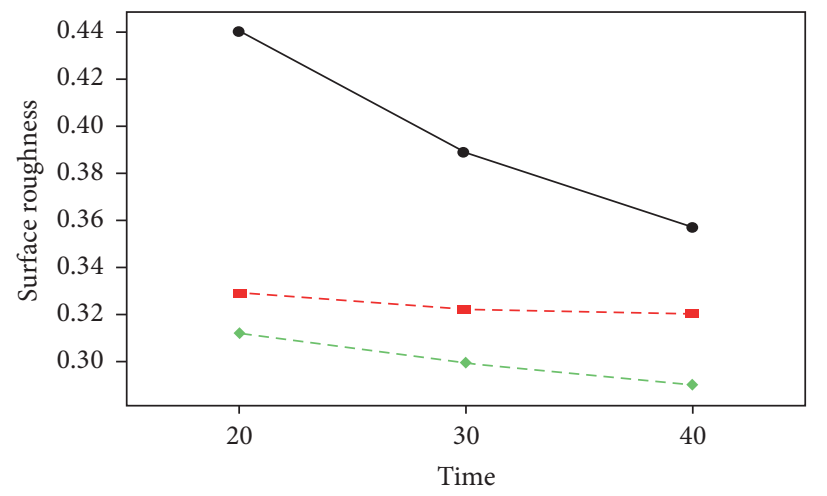

Concentration
$\rightarrow-500$
--550
--600

(c)

FIGURE 8: Interaction plots: (a) temperature and concentration, (b) temperature and time, (c) etchant concentration and time.

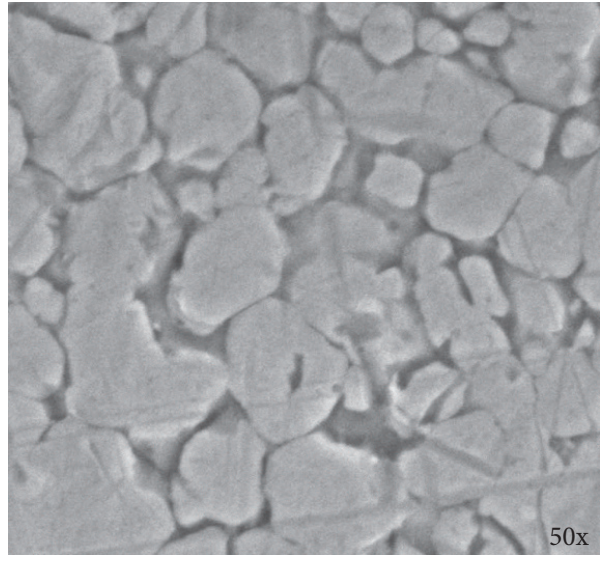

(a) Before machining

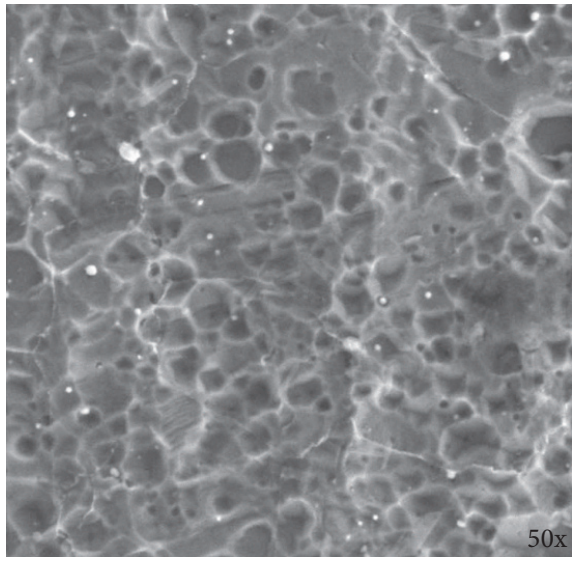

(b) After machining

FIGURE 9: SEM images showing the surface morphology of Inconel 718. 


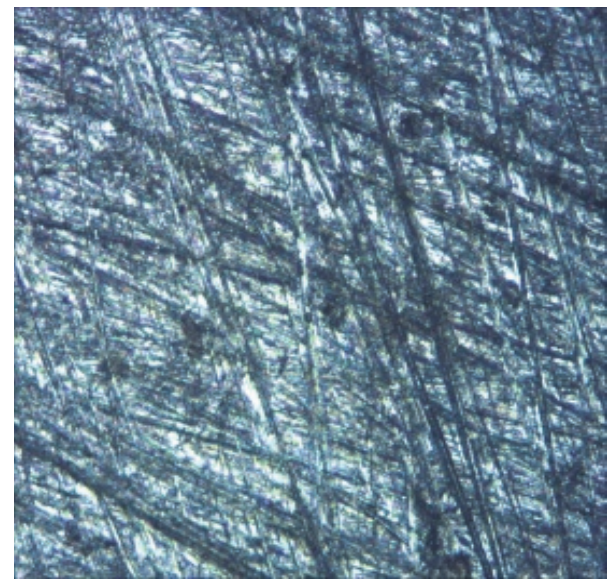

(a)

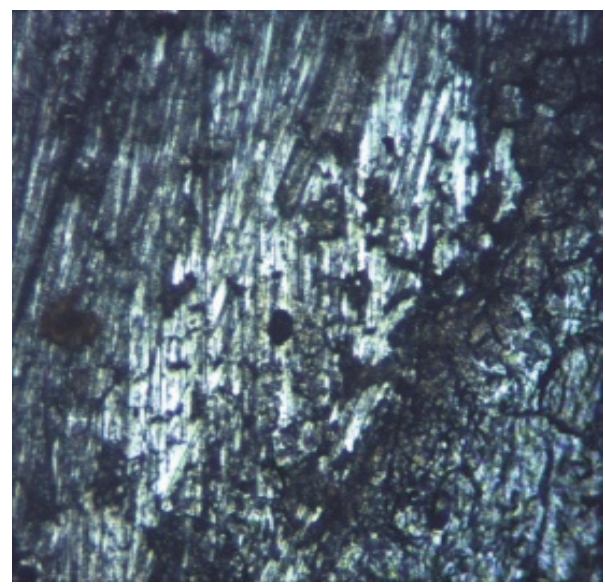

(c)

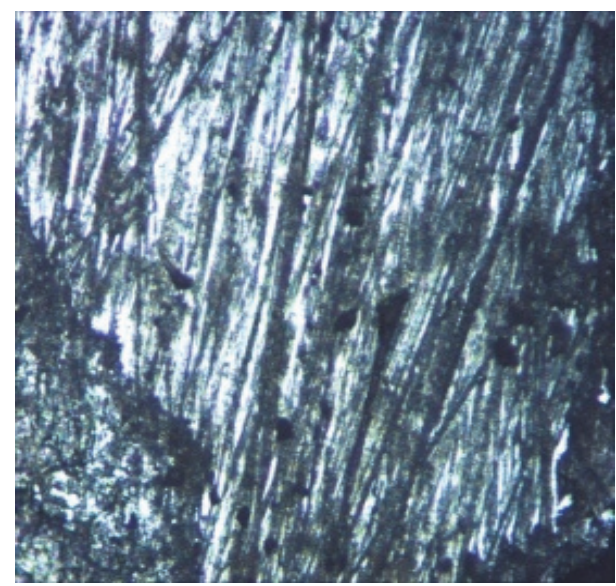

(b)

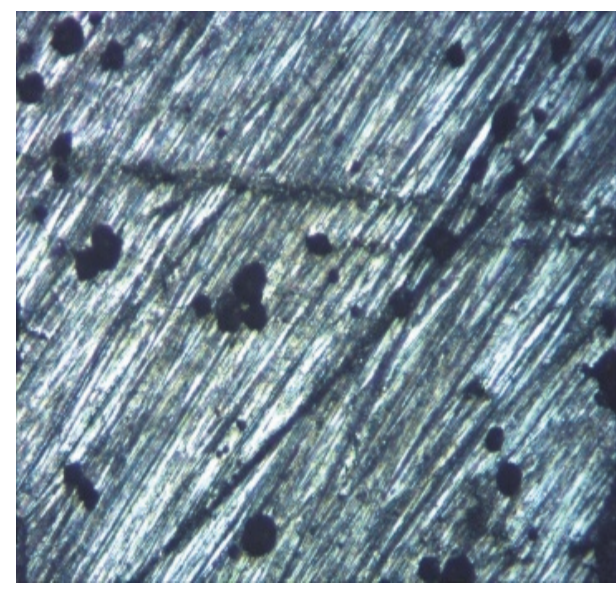

(d)

FiguRE 10: Microstructures of photochemically machined Inconel 718. (a) Before machining (b) at $45^{\circ} \mathrm{C}$; after machining (c) at $50^{\circ} \mathrm{C}$; after machining (d) at $55^{\circ} \mathrm{C}$; after machining (etchant concentration: $600 \mathrm{~g} / \mathrm{L}$ and etching time: 40 minute).

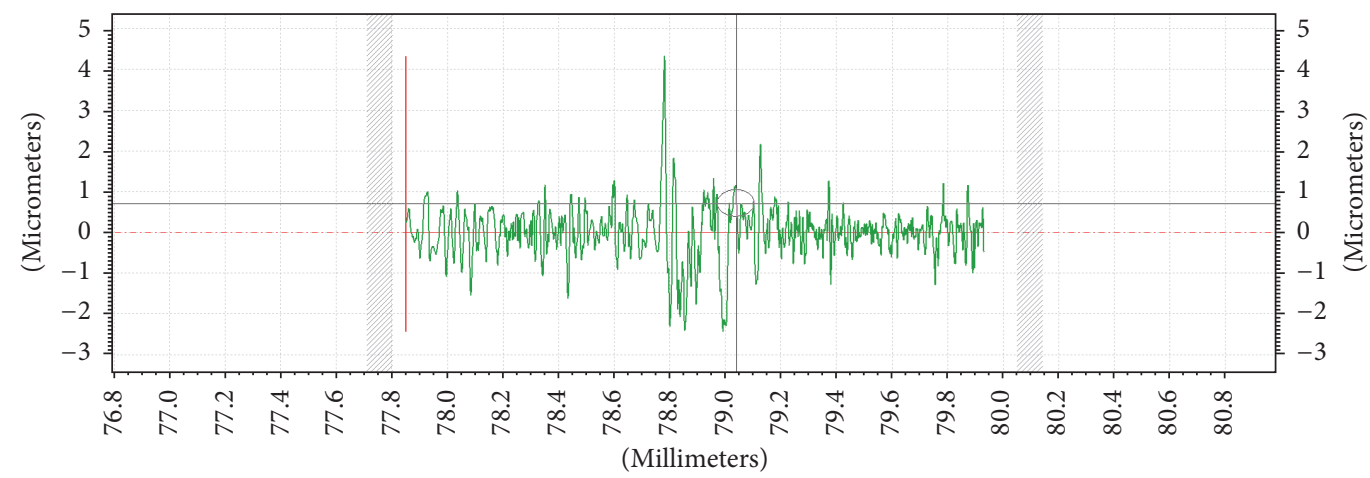

FIGURE 11: 2D roughness profile of Inconel 718 specimen (parameters: temperature: $45^{\circ} \mathrm{C}$, concentration: $600 \mathrm{~g} / \mathrm{L}$, and time: 40 minutes). 


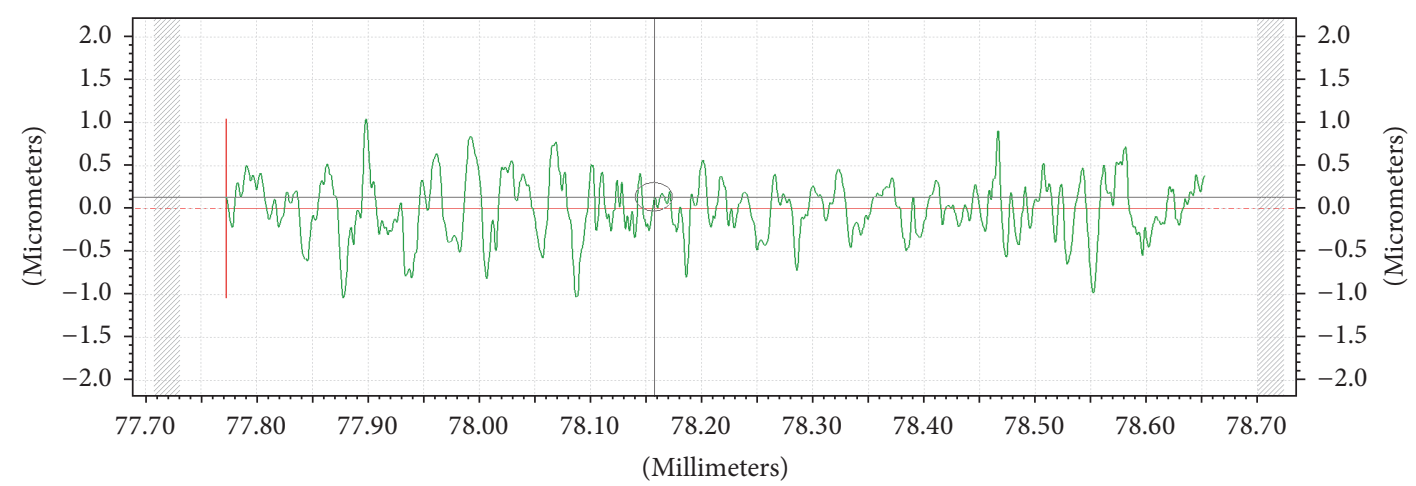

FIGURE 12: 2D roughness profile of Inconel 718 (parameters: temperature: $50^{\circ} \mathrm{C}$, concentration: $600 \mathrm{~g} / \mathrm{L}$, and time: 40 minutes).

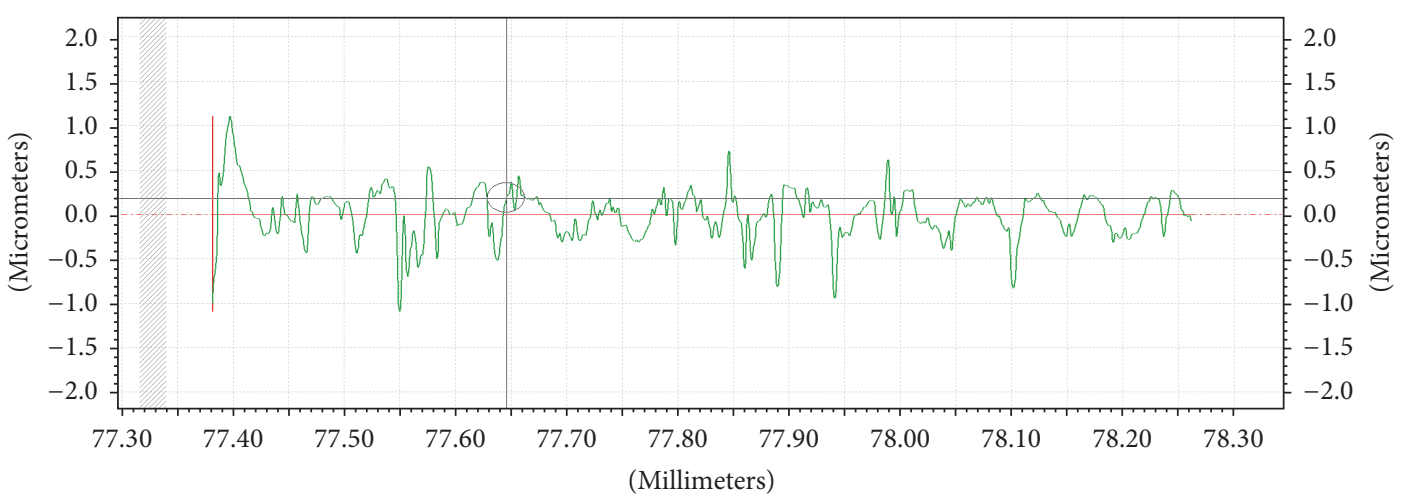

FIGURE 13: 2D surface roughness profile of machined Inconel 718 (parameters: temperature: $55^{\circ} \mathrm{C}$, concentration: $600 \mathrm{~g} / \mathrm{L}$, and time: 40 minutes).

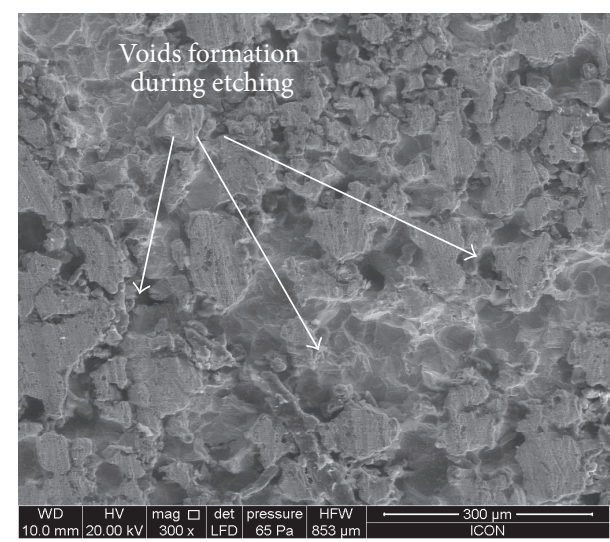

(a)

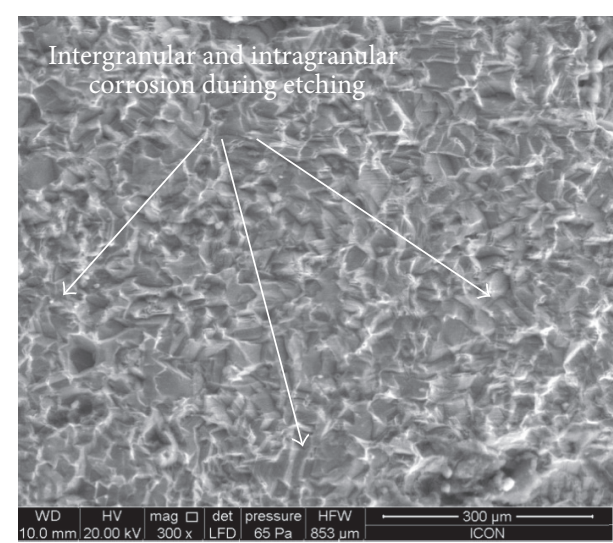

(b)

FIGURE 14: SEM image for a specimen photochemically machined at (a) $45^{\circ} \mathrm{C}$ and (b) $55^{\circ} \mathrm{C}$.

\section{Nomenclature}

PCM: Photochemical machining $\mathrm{FeCl}_{3}$ : Ferric chloride.

\section{Competing Interests}

The authors declare that there is no conflict of interests regarding the publication of this paper.

\section{References}

[1] D. M. Allen, The Principles and Practice of Photochemical Machining and Photoetching, Adam Hilger, IOP, Bristol, UK, 1986.

[2] D. M. Allen, "Photochemical machining: from 'manufacturing's best kept secret' to a $\$ 6$ billion per annum, rapid manufacturing process," CIRP Annals-Manufacturing Technology, vol. 53, no. 2, pp. 559-572, 2004.

[3] F. Fareh, V. Demers, N. R. Demarquette, S. Turenne, and O. Scalzo, "Molding properties of inconel 718 feedstocks used in 
low-pressure powder injection molding," Advances in Materials Science and Engineering, vol. 2016, Article ID 7078045, 7 pages, 2016.

[4] M. Dehmas, J. Lacaze, A. Niang, and B. Viguier, "TEM study of high-temperature precipitation of delta phase in inconel 718 alloy," Advances in Materials Science and Engineering, vol. 2011, Article ID 940634, 9 pages, 2011.

[5] A. R. Saraf and M. Sadaiah, "Magnetic field-assisted photochemical machining (MFAPCM) of SS316L," Materials and Manufacturing Processes, vol. 32, no. 3, pp. 327-332, 2016.

[6] D. H. Patil and S. Mudigonda, "The effect of the rolling direction, temperature, and etching time on the photochemical machining of monel 400 microchannels," Advances in Materials Science and Engineering, vol. 2016, Article ID 6751305, 9 pages, 2016.

[7] N. S. Qu, Y. Hu, D. Zhu, and Z. Y. Xu, "Electrochemical machining of blisk channels with progressive-pressure electrolyte flow," Materials and Manufacturing Processes, vol. 29, no. 5, pp. 572578, 2014.

[8] A. A. G. Bruzzone and A. P. Reverberi, "An experimental evaluation of an etching simulation model for photochemical machining," CIRP Annals_Manufacturing Technology, vol. 59, no. 1, pp. 255-258, 2010.

[9] O. Çakir, “Chemical etching of aluminium," Journal of Materials Processing Technology, vol. 199, no. 1, pp. 337-340, 2008.

[10] S. Ho, T. Nakahara, and G. D. Hibbard, "Chemical machining of nanocrystalline Ni," Journal of Materials Processing Technology, vol. 208, no. 1-3, pp. 507-513, 2008.

[11] O. Çakir, H. Temel, and M. Kiyak, "Chemical etching of Cu-ETP copper," Journal of Materials Processing Technology, vol. 162-163, pp. 275-279, 2005.

[12] D. M. Allen and H. J. A. Almond, "Characterisation of aqueous ferric chloride etchants used in industrial photochemical machining," Journal of Materials Processing Technology, vol. 149, no. 1-3, pp. 238-245, 2004.

[13] R. P. Yadav and S. N. Teli, "A Review of issues in photochemical machining," International Journal of Modern Engineering Research, vol. 4, no. 7, pp. 49-53, 2014.

[14] O. Cakir, "Copper etching with cupric chloride and regeneration of waste etchant," Journal of Materials Processing Technology, vol. 175, no. 1-3, pp. 63-68, 2006.

[15] A. B. Bhasme and M. S. Kadam, "Parameter optimization by using grey relational analysis of photochemical machining," International Research Journal of Engineering and Technology, vol. 3, no. 3, pp. 992-997, 2016.

[16] A. B. Bhasme and M. S. Kadam, "Experimental investigation of PCM using response surface methodology on SS316L steel," International Journal of Mechanical Engineering and Technology, vol. 7, no. 2, pp. 25-32, 2016.

[17] P. Mumbare and A. J. Gujar, "Multi objective optimization of photoche-mical machining for ASME 316 steel using grey relational analysis," International Journal of Innovative Research in Science, Engineering and Technology, vol. 5, no. 7, pp. 1241812425, 2016.

[18] S. S. Wangikar, P. K. Patowari, and R. D. Misra, "Effect of process parameters and optimization for photochemical machining of brass and german silver," Materials and Manufacturing Processes, pp. 1-9, 2016. 

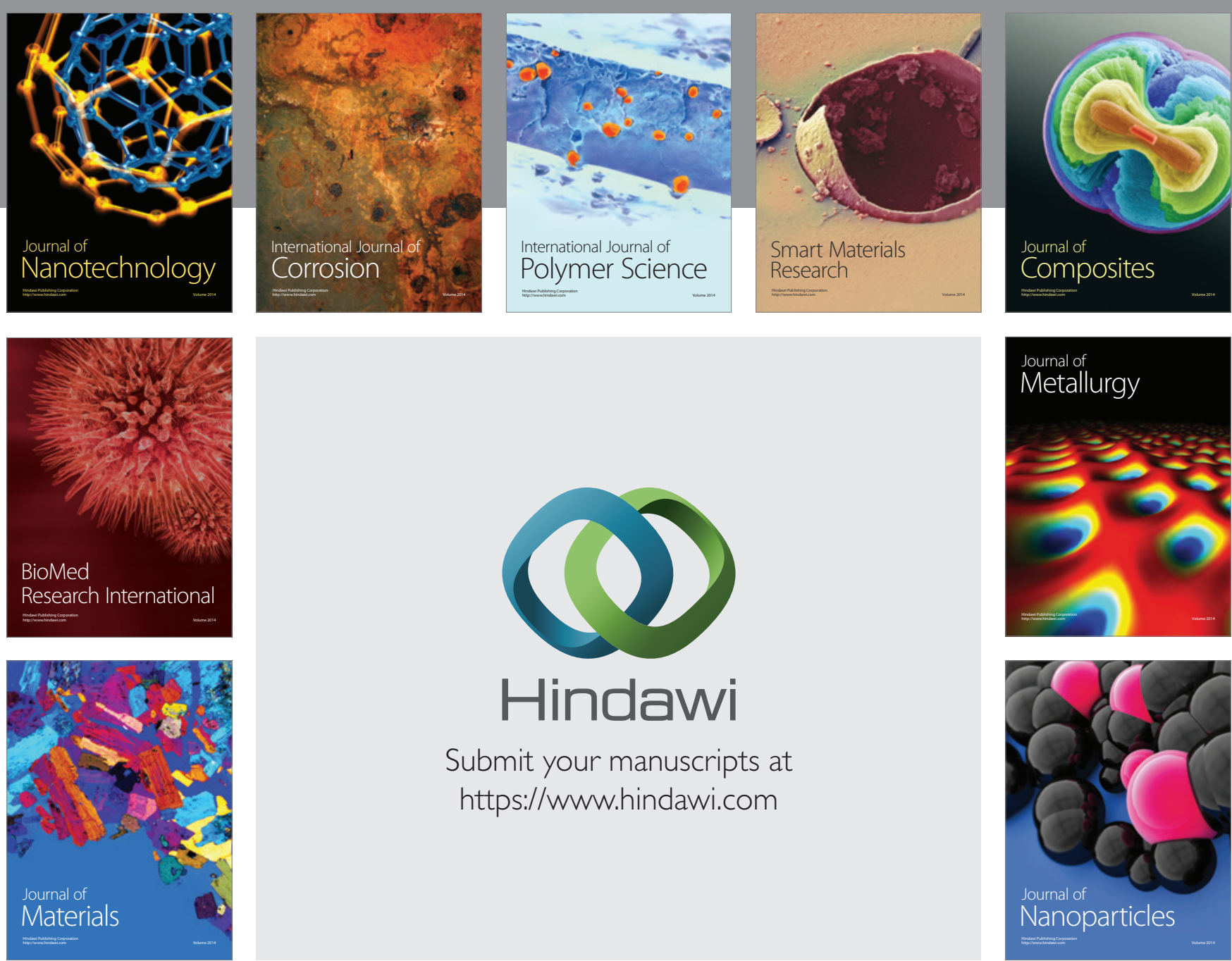

\section{Hindawi}

Submit your manuscripts at

https://www.hindawi.com

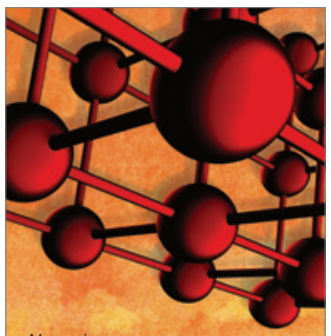

Materials Science and Engineering
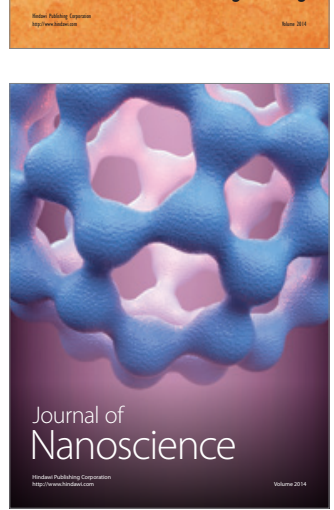
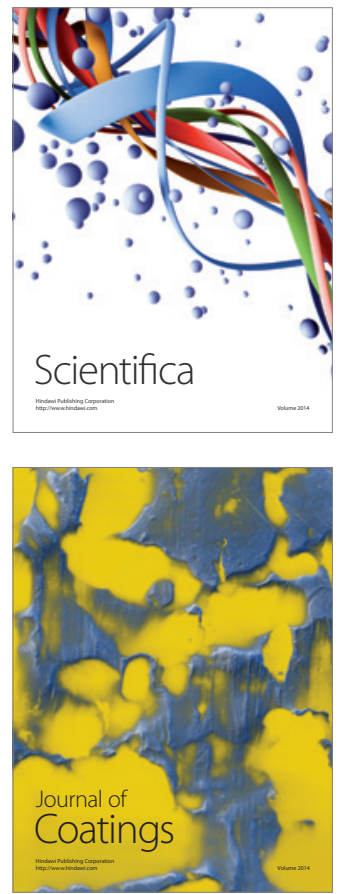
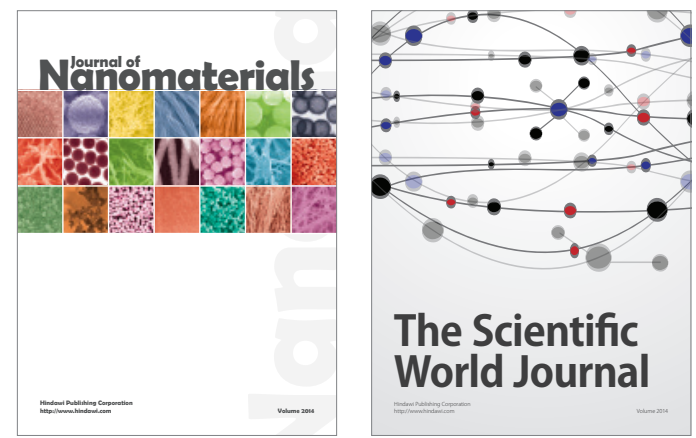

The Scientific World Journal
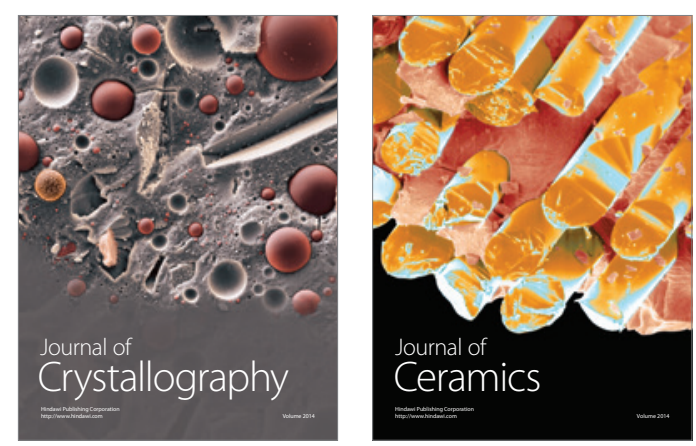
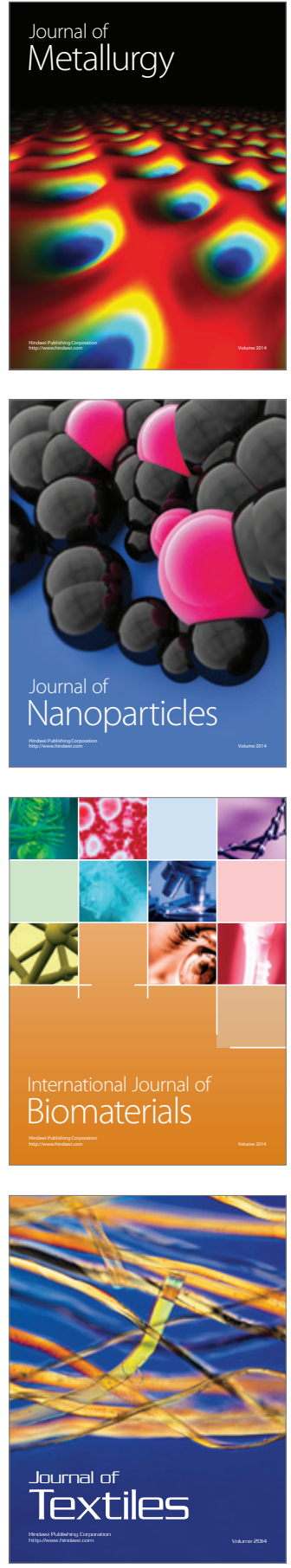